\title{
Ophiochloa bryoides (Poaceae, Paniceae), a New Grass Species from Central Brazil
}

\author{
Gabriel H. Rua, ${ }^{1,3,4}$ Regina C. Oliveira, ${ }^{2}$ and José F. M. VAlls ${ }^{3}$ \\ ${ }^{1}$ Cátedra de Botánica Agrícola, Facultad de Agronomia, Universidad de Buenos Aires, Av. San Martín 4453, \\ C1417DSE Buenos Aires, Argentina; \\ ${ }^{2}$ Herbário Dárdano de Andrade Lima, Universidade Federal Rural do Semi-Árido, Caixa Postal 137, CEP \\ 59600-970, Mossoró, RN, Brazil; \\ ${ }^{3}$ EMBRAPA / Recursos Genéticos e Biotecnologia, PqEB Parque Estação Biológica, Final W-5 Norte, Caixa \\ Postal 02372, CEP 70770-900, Brasília, DF, Brazil \\ ${ }^{4}$ Author for correspondence (gabriel@cenargen.embrapa.br)
}

\section{Communicating Editor: Thomas G. Lammers}

\begin{abstract}
Aвstract. Ophiochloa bryoides, a new species in the Brazilian endemic genus Ophiochloa, is described and illustrated. It is similar to O. hydrolithica, the only currently known species in this genus, from which it differs because of its diminutive annual habit, the absence of an axillary inflorescence, and the occurrence of a single apical seta on the lower lemma. The affinity of Ophiochloa with Axonopus is briefly discussed.

Resumo. Ophiochloa bryoides, uma nova espécie de Ophiochloa, um gênero endêmico do Brasil, é descrita e ilustrada. A espécie é relacionada à $O$. hydrolithica, a única espécie conhecida desse gênero, da qual difere pelo hábito anual, pelo tamanho diminuto, pela ausência de uma inflorescência axilar, e pela ocorrência de uma única seta apical no lema inferior. A afinidade de Ophiochloa com Axonopus é discutida brevemente.
\end{abstract}

KeYwords: Axonopus, Brazil, Ophiochloa, Paniceae, Poaceae, serpentinic flora.

The genus Ophiochloa Filg., Davidse \& Zuloaga (1993) was described to accomodate an odd grass species found in serpentine soils in the municipality of Niquelândia, in the Brazilian state of Goiás. It was characterized by solitary, unilateral, winged racemes ending in a sterile projection, adaxial spikelets, distinct, narrow 2-nerved lower lemma with two prominent setae, upper lemma and palea tips hyaline, free, and ligule represented by a row of hairs (Filgueiras et al. 1993).

During a recent botanical survey, a new species of Ophiochloa was found near São Jorge, municipality of Alto Paraíso, in the Brazilian state of Goiás. The new species is described, illustrated, and compared with $O$. hydrolithica Filg., Davidse \& Zuloaga, the other species of the genus.

\section{TAXONOMIC TREATMENT}

Ophiochloa bryoides G. H. Rua, R. C. Oliveira \& Valls, sp. nov. (Fig. 1).-TYPE here designated: BRAZIL. Goiás: mun. Alto Paraíso, Chapada dos Veadeiros, ca. $5 \mathrm{~km}$ SE of São Jorge, Rio São Miguel, Vale da

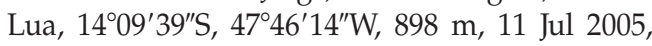
G. H. Rua \& R. C. Oliveira 641 (holotype: CEN!; isotypes: BAA! L! RB! US!).

Ophiochloae hydrolithicae Filg., Davidse \& Zuloaga affinis sed habitu annuo, omnibus partibus multo minoribus, inflorescentia axillari nulla, seta apicis lemmatis inferioris unica differt.

Annual, minute, moss-like grass ca. $5 \mathrm{~cm}$ tall, forming dense patches. Basal nodes bearing 6-9 foliage leaves in the main axis, fewer in lateral tillers, separated by short internodes; lateral tillers $1-3$, up to second branching order, similar in structure to the main axes, all coming to flowering. Culms $3-6.5 \mathrm{~cm}$ long, ca. $0.12 \mathrm{~mm}$ wide, strongly geniculate, composed of 4-5 internodes, glabrous, pale; nodes purple-tinged, glabrous. Leaf sheaths 6-12 mm long, rounded on the back, ribbed, glabrous, margins free, hyaline, glabrous. Ligules a minute fringe of hairs, less than $0.1 \mathrm{~mm}$ long, the hairs behind the ligule to $1.2 \mathrm{~mm}$ long, ligular regions constricted. Lower leaf blades $2-3 \mathrm{~cm}$ long, $0.2-0.3 \mathrm{~mm}$ wide, falciform-setaceous, plicate, 3-nerved, V-shaped in cross section; bases attenuate, apices acuminate, glabrous. Upper leaf blade shorter yet well developed, expanded. Peduncles 8-30 $\mathrm{mm}$ long, filiform, ribbed, flexuous, glabrous. Terminal inflorescences exserted, composed of a single, unilateral, spike-like paraclade, 8-20 mm long, drooping at maturity; pulvini glabrous to pubescent, purple-tinged; rachises $0.3-0.4 \mathrm{~mm}$ wide, glabrous, winged, abaxially ridged, ending in an acuminate naked extremity, central portions light green, sinuous, 5-6-nerved, wings and abaxial ridges hyaline, colorless, enfolding the spikelets; pedicels adnate to the rachis, inconspicuous. Axillary inflorescences lacking. Spikelets solitary, bisexual, soft, awnless, alternating on each side of the rachis keel, dorsiventrally compressed, adaxial, narrowly ovate, disarticulating below the glumes and falling as a unit. Lower glumes lacking. Upper glumes longer than the upper florets, $1.4-1.6 \mathrm{~mm}$ long, $0.4-0.5 \mathrm{~mm}$ wide, narrowly triangular-ovate, hyaline, colorless, glabrous, sparsely covered with prickle hairs, clasping the upper florets, apices acute, erose. Lower florets consisting only of a lemma, $0.6-0.8 \mathrm{~mm}$ long, $0.1-0.2 \mathrm{~mm}$ wide, narrow, acute, not clasped by the upper glumes, strongly 2-nerved, nerves stout, marginal, light brown, intercostal regions hyaline; densely ciliate at the base and along the nerves, cilia $0.2-0.9 \mathrm{~mm}$ long, one subterminal cilium 4.5-6 mm long, attached to one side of the lemma margins, stout, hygroscopic at maturity. Upper florets $1.2-1.3 \mathrm{~mm}$ long, $0.2-0.3 \mathrm{~mm}$ wide, narrowly ovate, bisexual. Fertile lemmas membranous, brown, glabrous, apices acute, hyaline, colorless, indistinctly nerved, the proximal portion of the margins embracing the fertile palea. Fertile paleas 2-nerved, brown-tinged laterally, intercostal regions hyaline, colorless, apices with two small lobes; lodicules not seen; stamens 2, anthers ca. 0.5-0.6 mm long, yellow; stigmas 2, pale, plumose. Caryopses narrowly oblong-ovate, $0.7-0.8 \mathrm{~mm}$ long, $0.2 \mathrm{~mm}$ wide, with persistent stylar bases, pale, embryos ca. $0.3 \mathrm{~mm}$ long, hilum oblong-elliptic, ca. $0.2 \mathrm{~mm}$ long. 


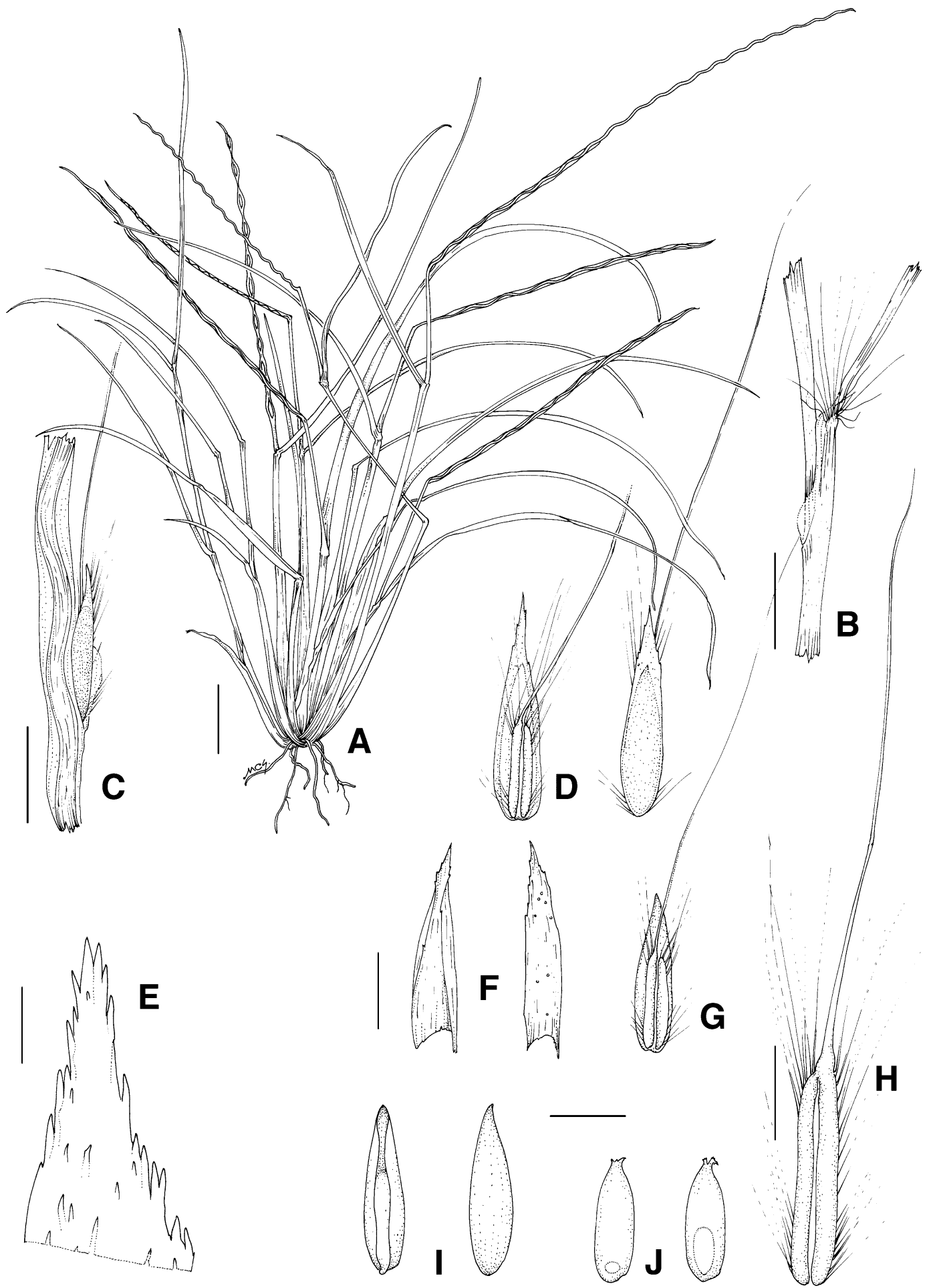

FIG. 1. Ophiochloa bryoides (G. H. Rua \& R. C. Oliveira 641). A. Habit. B. Detail of the ligular region. C. Portion of rachis with one spikelet, adaxial view. D. Spikelet, adaxial (left) and abaxial (right) views. E. Upper glume, apex. F. Upper glume, adaxial (left) and abaxial (right) views. G. Spikelet, adaxial view, the upper glume removed. H. Lower lemma, abaxial view. I. Upper floret, adaxial (left) and abaxial (right) views. J. Caryopsis, hilum side (left) and embryo side (right). Drawn by M. Cecilia Scoones. 
Distribution and Habitat. The new species was found in the Chapada dos Veadeiros, state of Goiás, Brazil, at the site known as "Vale da Lua" (Moon Valley), a series of rapids and stream holes in the river bed of the "Ribeirão São Miguel" (Dardenne and Campos 2002), where it grows forming moss-like patches on the river margin. It is a rocky place rich in calcium, iron and magnesium carbonates (calcite, dolomite, ankerite), with additional occurrence of magnesium-rich clays (montmorillonite group), and probably low levels of some plant macronutrients as phosphorus and available potassium (C. F. Monteiro and J. E. G. Campos, in mss.).

\section{DISCUSSION}

The new species of Ophiochloa differs from $O$. hydrolithica because of its annual habit and the very diminutive size of all vegetative and reproductive parts, as well as by absence of an axillary inflorescence, and by having a single subterminal seta on the lower lemma.

Although the genus Ophiochloa was originally included in the subtribe Digitariinae Butzin (Filgueiras et al. 1993), a recent molecular study showed it to be related to Axonopus P. Beauv. (Giussani et al. 2001; Aliscioni et al. 2003). In this study, the possible inclusion of Ophiochloa within Axonopus was suggested, although such a relationship was not resolved in the consensus. In spite of some autoapomorphies that make Ophiochloa distinct, its placement near Axonopus is supported by an array of morphological characters: unilateral spike-like inflorescences, a more or less winged rachis with an abaxial ridge or crest, axillary inflorescence branching (in O. hydrolithica), solitary, subsessile to sessile, adaxial spikelets, lower glume lacking, upper glume (in O. hydrolithica) and lower lemma usually 2nerved (midvein lacking). Within Axonopus, species belonging to different infrageneric taxa share additional characters with Ophiochloa: dark upper florets are found in sect. Lappagopsis (Steud.) Chase and sect. Cabrera (Lag.) Chase; spikelets embedded into the rachis occur in A. chrysoblepharis (Lag.) Chase, of the sect. Cabrera; inflorescences composed of a single spike-like paraclade occur occasionally in the series Fastigiati G. A. Black, and white, tubercle-based cilia are present in the spikelets of Lappagopsis and Fastigiati (Black 1963). Whether Ophiochloa deserves generic status or is a highly apomorphic clade within Axonopus remains an open question.

The genus Ophiochloa has been circumscribed as a serpentine endemic of the ultramafic rock belt of the cerrado vegetation of central Brazil (Filgueiras et al. 1993). The occurrence of a serpentinic adapted flora has been reported elsewhere (Brooks et al. 1990) for the serpentine outcrops in the municipality of Niquelândia, near and around the locality of Macedo, where the type species $O$. hydrolithica was collected for the first time. This region lies about $80 \mathrm{~km}$ WSW from the type locality of $O$. bryoides. Several new grass species in addition to $O$. hydrolithica have been described from the Macedo-Niquelândia region in recent years, all belonging to the genus Paspalum: P. longiaristatum Davidse \& Filg. (Davidse and Filgueiras 1993), P. biaristatum Filg. \& Davidse (Filgueiras and Davidse 1994), P. niquelandiae Filg. (Filgueiras 1995), and P. burmanii Filg., Morrone \& Zuloaga (Filgueiras et al. 2001). The finding of $O$. bryoides casts doubts on the strictly serpentine endemicity of the genus Ophiochloa. Nevertheless, both species of this highly specialized grass genus are adapted to soils with high concentrations of heavy metals and relatively low levels of some macronutrients. Remarkably, in the same area where O. bryoides was discovered, a population of Paspalum longiaristatum, another supposedly serpentine endemic, was also found.

The specific epithet refers to the moss-like habit of this minute, annual grass.

\section{Key tO the Species of OphiOchloA}

1. Caespitose perennial, $50-80 \mathrm{~cm}$ tall. Uppermost leaf usually with an axillary inflorescence branch. Spikelet $2.3-3.1 \mathrm{~mm}$ long. Upper glume faintly 2-nerved. Lower lemma with two long, hygroscopic apical setae . . . . . . . . . . . . . O . hydrolithica

1. Dwarf annual, up to $5 \mathrm{~cm}$ tall. Uppermost leaf without an axillary inflorescence branch. Spikelet 1.4-1.6 mm long. Upper glume 0 -nerved. Lower lemma with a single long, hygroscopic apical seta

O. bryoides

ACKNOWLEDGEMENTS. We are indebted to J. Eloi Guimarães Campos for worthy comments on the geology of the typical locality, to Roberto D. Tortosa and Tarciso S. Filgueiras for critical revision of the manuscript, to $\mathrm{M}$. Cecilia Scoones for the excellent illustrations, and to Taciana B. Cavalcanti for continuous, willing help. This work received financial support through fellowships to GHR and JFMV from the "Conselho Nacional de Desenvolvimento Científico e Tecnológico (CNPq)", Brazil. GHR is a member of the "Carrera del Investigador" of the "Consejo Nacional de Investigaciones Científicas y Técnicas (CONICET)", Argentina.

\section{Literature Cited}

Aliscioni, S. S., L. M. Giussani, F. O. Zuloaga, and E. A. KelLOGG. 2003. A molecular phylogeny of Panicum (Poaceae:
Paniceae): tests of monophyly and phylogenetic placement within the Panicoideae. American Journal of Botany 90: 796821.

BLACK, G. A. 1963. Grasses of the genus Axonopus (a taxonomic treatment). Advancing Frontiers of Plant Sciences 5: 1-186.

Brooks, R. R., R. D. ReEves, A. J. M. BAKer, J. A. Rizzo, and H. D. FERREIRA. 1990. The Brazilian serpentine expedition (Braspex), 1988. National Geographic Research 6: 205-219.

DARDENNe, M. A. and J. E. G. CAmpos. 2002. Parque Nacional da Chapada dos Veadeiros, GO-Sítio de grande beleza cênica do centro-oeste brasileiro. Pp. 323-333 in Sitios geológicos e paleontológicos do Brasil, v. 1, eds. C. Schobbenhaus, D. A. Campos, E. T. Queiroz, M. Winge, and M. L. C. Berbert-Born. Brasília: SIGEP.

DAVIDSE, G. and T. S. FILgueIrAs. 1993. Paspalum longiaristatum (Po- 
aceae: Paniceae), a new serpentine endemic from Goiás, and the first awned species in the genus. Novon 3: 129-132.

FilgueIRAS, T. S. 1995. Paspalum niquelandiae (Poaceae: Paniceae), a new species from serpentine outcrops of central Brazil. Nowon 5: 30-33.

and G. DAvidse. 1994. Paspalum biaristatum (Poaceae: Paniceae), a new serpentine endemic from Goiás, Brazil, and the second awned species in the genus. Novon 4: 18-22.

- _ - and F. O. ZuloagA. 1993. Ophiochloa, a new en- demic serpentine grass genus (Poaceae: Paniceae) from the Brazilian cerrado vegetation. Novon 3: 360-366.

- , O. Morrone, and F. O. Zuloaga. 2001. Paspalum burmanii (Poaceae: Paniceae), a new species from central Brazil. Nowon 11: 36-39.

Giussani L. M., H. Cota-SÁnchez, F. O. Zuloaga, and E. A. KelLOGG. 2001. A molecular phylogeny of the grass subfamily Panicoideae (Poaceae) shows multiple origins of C4 photosynthesis. American Journal of Botany 88: 1993-2012. 